\title{
HUBUNGAN POLA ASUH ORANG TUA DENGAN PERILAKU BERPACARAN PADA REMAJA DI SMAN 6 DEPOK
}

\author{
Tri Septi Ulan Dari ${ }^{1}$, Diah Ratnawati ${ }^{2}$ \\ S1 Keperawatan Fakultas Ilmu-ilmu Kesehatan \\ Universitas Pembangunan Nasional "Veteran" Jakarta \\ Jln. Limo Raa, Depok \\ E-mail :Triseptiulandari@gmail.com
}

\begin{abstract}
Abstrak
Penelitian ini dilakukan untuk mengetahui apakah ada hubungan antara pola asuh orang tua dengan perilaku berpacaran pada remaja. Pacaran merupakan suatu tahapan untuk mencari pasangan hidup dan melangsungkan pernikahan, namun belakang ini orientasi pacaran sudah berubah dikalangan remaja. Dewasa ini kondisi pacaran remaja lebih kearah yang tidak sehat, gaya pacaran remaja sekarang sudah mengarah kepada perilaku yang diluar batas dimana mereka sudah sampai ke hubungan seksual. Kondisi tersebut disebabkan oleh banyak hal yaitu melalui pola asuh orang tua, pola asuh orang tua disini berpengaruh terhadap gaya berpacaran pada remaja. Metode yang digunakan dalam peneltian ini adalah deskripif analitik kuantitatif dengan pendekatan crosssectional dengan jumlah sampel 187 responden. Analisa yang digunakan adalah analisa univariat dan bivariat. Analisa bivariat dengan menggunakan uji chi-square. Hasil penelitian dengan analisa univariat menunjukan 101 (54\%) responden yang memiliki pola asuh baik dan $113(60,4 \%)$ responden yang memiliki perilaku berpacaran sehat. Analisa bivariat menunjukan adanya hubungan yang bermakna antara hubungan pola asuh orang tua dengan perilaku berpacaran pada remaja dengan $\mathrm{P}$ value $=0,004$ (P value $<\alpha 0,005$ ). Dapat disimpulkan bahwa pola asuh yang dimiliki remaja di SMAN 6 Depok adalah pola asuh yang baik dan perilaku berpacaran remajanya adalah pacaran yang sehat. Saran peneliti bagi orang tua yaitu memberikan pola asuh yang baik kepada anak-anaknya sehingga perilaku anak menjadi baik sesuai yang diajarkan oleh orang tuanya.
\end{abstract}

Kata kunci: Remaja, Pola asuh orang tua, Perilaku berpacaran

\section{PENDAHULUAN}

Masa remaja merupakan masa peralihan antara masa kanak-kanak dan masa dewasa, yang dimulai pada saat terjadinya kematangan seksual (Soetjiningsih 2010, hlm.45). Berdasarkan batasan usia dikatakan remaja bila usianya mencapai 11 atau 12 tahun sampai dengan 20 tahun yaitu menjelang masa dewasa muda (Soetjiningsih 2010, hlm.45). Selain itu, Potter dan Perry (2009, hlm.45) mengelompokkan dalam batasanbatasan usia menjadi tiga bagian yaitu usia 11 sampai 14 tahun adalah masa remaja awal, 15 sampai 17 tahun adalah masa remaja pertengahan, 18 sampai 20 tahun adalah masa remaja akhir. Aini (2012, hlm.1) mengemukakan bahwa masa remaja adalah masa yang penuh gejolak, termasuk pengalaman berinteraksi dengan lawan jenis sebagai bekal 
manusia untuk mengisi kehidupan mereka nantinya.

Masa remaja adalah suatu masa perubahan, perubahan-perubahan ini meliputi perubahan fisik, perubahan psikologis dan perubahan psikososial. Pada masa ini terjadi perubahan yang cepat baik secara fisik maupun psikologis diantaranya peningkatan emosional, kematangan seksual, ketertarikan dengan orang lain, perubahan nilai dan kebanyakan remaja yang bersikap ambivalen (Jahja 2011, hlm.219). Proses pertumbuhan fisik termasuk perubahan hormonal lebih cepat dari pada perkembangan psikososial, hal ini menyebabkan remaja memiliki karakteristik yang khas yaitu mempunyai keingintahuan yang besar, menyukai pengalaman dan tantangan serta cenderung nekat mengambil resiko terhadap sesuatu yang diinginkan tanpa pertimbangan yang matang (Depkes, 2005).

Karakteristik remaja pada masa awal mempunyai keinginan untuk mendekati dan menjalin hubungan dengan lawan jenisnya. Dorongan tersebut yang diakibatkan karena mulai matangnya organ seks (Andriani \& Wirjatmadi 2012, hlm.291). Adanya dorongan seksual ini, perilaku remaja mulai diarahkan untuk menarik perhatian lawan jenis dan dalam rangka mencari pengetahuan mengenai seks, ada remaja yang melakukannya dengan cara terbuka bahkan mulai mencoba bereksperimen dalam kehidupan seksual, misalnya melalui pacaran (Musthofa 2010, hlm.10).

Pacaran merupakan suatu tahapan yang dilalui sebelum melangsungkan pernikahan. Pacaran merupakan suatu proses untuk mencurahkan atau mengungkapkan segala isi hati antar pasangan yang berlawan jenis yang saling menyayangi, mengasihi, dan mencintai. Orientasi berpacaran pada remaja telah berubah, dulu tujuan dari berpacaran adalah untuk mencari calon pasangan hidup seperti suami atau istri, namun saat ini tujuan dari pacaran adalah untuk gengsi, fantasi, bahkan eksplorasi seks (Hanifah 2010, hlm.13).

Gaya pacaran remaja sekarang sudah mengarah kepada perilaku yang diluar 
batas, disinilah mulai muncul masa pacaran yang didalamnya terkait perilaku seks untuk mengisi waktu senggang mereka dan tidak menutup kemungkinan untuk melakukan perilaku seks yang tidak semestinya mereka lakukan. Pacaran tentunya memiliki efek dan bias terhadap kehidupan masing-masing baik secara positif maupun negatif. Pacaran positif merupakan pacaran sehat, yaitu pacaran yang memenuhi kriteria " sehat", baik secara fisik, psikis, social, maupun seksual. Jika pacaran melewati batasan-batasan kewajaran seperti kissing, necking, petting dan menjerumus ke perilaku seksual / intercourse, maka ini sudah tidak bisa dikatakan sebagai pacaran yang sehat atau pacaran negatif (Budi dalam Amali 2012, hlm.1).

Kondisi pacaran remaja dewasa ini lebih kearah yang tidak sehat, hal tersebut dibuktikan dengan data dari Youth Risk Behavior Survei (YRBS) secara Nasional di Amerika Serikat pada tahun 2006 mendapati bahwa $47,8 \%$ pelajar yang duduk di kelas 9 12 telah melakukan hubungan seks, $35 \%$ pelajar SMA telah aktif secara seksual (dalam Banun 2013, hlm.1). Berdasarkan Survei Kesehatan Reproduksi Remaja Indonesia (SKRRI, 2012), beberapa perilaku berpacaran remaja yang belum menikah sangat mengkhawatirkan.

Sebanyak 29,5 persen remaja pria dan $6,2 \%$ remaja wanita pernah meraba atau merangsang pasangannya. Sebanyak 48,1 \% remaja laki-laki dan $29,3 \%$ remaja wanita pernah berciuman bibir. Sebanyak 79,6 \% remaja pria dan $71,6 \%$ remaja wanita pernah berpegangan tangan dengan pasangannya. Bahkan dalam survei tersebut juga terungkap, umur berpacaran untuk pertama kali paling banyak adalah 15-17 tahun, yakni pada $45,3 \%$ remaja pria dan $47,0 \%$ remaja wanita. Berdasarkan seluruh usia yang di survey yakni 10-24 tahun, hanya $14,8 \%$ yang mengaku belum pernah pacaran sama sekali (dalam Dimyanti 2013, hlm.1), sedangkan dari hasil survey BKKBN Jawa Barat pada 1000 remaja yaitu 100 diantaranya sudah tidak perawan lagi dan 80 diantaranya sudah memiliki anak, faktor yang mengakibatkan remaja tidak perawan 
lagi adalah pergaulan bebas (Heryana 2011, hlm.6). Berdasarkan penelitian terdahulu yang dilakukan peneliti di SMAN 6 Depok dengan mewawancarai Guru Pembimbing Konseling (BK) terlihat fenomena bahwa siswa/siswi SMAN 6 Depok terlihat gaya berpacaran mereka bermacam-macam. Peneliti mengetahui lebih dalam dengan mewawancarai 11 siswa/siswi didapatkan hasil bahwa 11 siswa/siswi berperilaku pacaran dengan berbagai macam perilaku pacaran seperti berkomunikasih dengan handphone, saling mengobrol pada saat berduaan, berpelukan, pegangan tangan, mencium pipi atau kening, berciuman bibir, menyentuh bagan sensitif.

Tersebut diatas pemerintah melalui BKKBN telah merespon permasalahan remaja dengan mengembangkan Program Genre bagi remaja dan keluarga yang memiliki remaja. Program Generas Berencana adalah suatu program yang dikembangkan dalam rangka penyiapan kehidupan keluarga bagi remaja yang diarahkan untuk mencapai cita-cita demi terwujudnya keluarga kecil, bahagia dan sejahtera. Program GenRE ditunjukan kepada remaja melalui wadah Pusat Informasi dan Konseling Remaja atau Mahasiswa (PIK Remaja) dan keluarga yang memiliki remaja melalui wadah Bina Keluarga Remaja (BKR) (Mardiya 2013, hlm.15).

Perilaku pacaran berlebihan ini yang mengarah mengarah pada perilaku seksual adalah hamil yang tidak dikehendaki dan akhirnya melakukan tindakan aborsi karena belum siapnya pasangan tersebut untuk membangun sebuah keluarga, penyakit menular seksual (PMS) dan dampak pada psikologis, yaitu perasaan bingung, cemas, malu, dan bersalah yang dialami remaja setelah mengetahui kehamilannya bercampur dengan perasaan depresi, pesimis terhadap masa depan, dan kadang disertai rasa benci dan marah baik kepada diri sendiri maupun kepada pasangannya (Amalia 2012, hlm.2). Selain itu perilaku pacaran memiliki dampak positif maupun negatif yang lain yaitu dampak positif dalam prestasi sekolah adalah pacaran dapat meningkatkan 
prestasi karena semangat belajar yang naik akibat ada pacar yang senantiasa memberikan dorongan dan perhatian. Dampak negatifnya adalah prestasi belajar menurun jika ada permasalahan yang cukup berat sehingga mengganggu konsentrasi dan semangat belajar atau seseorang tersebut lebih senang menghabiskan waktu bersama pacar dari pada belajar. Serta dampak negatif dalam pergaulan sosial dengan teman sebaya maupun lingkungan sosial menjadi sempit jika sepasang kekasih lebih menghabiskan waktunya hanya berdua, tidak mau bergaul dengan teman lain dan hubungan dengan keluarga pun menjadi renggang karena waktu luang lebih banyak dihabiskan dengan pacar (Sejati 2008,hlm.35). Kondisi tersebut disebabkan oleh banyak hal, salah satunya menurut Amalia (2012, hlm.7), adalah melalui pola asuh orang tua, pola asuh orang tua disini berpengaruh terhadap gaya berpacaran pada remaja karena ketidakkonsistenan orang tua dalam menerapkan pola asuh sehingga membuat remaja bingung dalam menentukan sikapnya. Remaja sering merasa minder dan kurang percaya diri dalam mengungkapkan masalah yang mereka hadapi karena mereka sendiri tidak yakin dengan harapan orang tua kepadanya. Hasil yang dilakukan Aguma (2013, hlm.5) bahwa pola asuh orang tua dengan perilaku seksual remaja diperoleh bahwa remaja yang berperilaku seksual tidak beresiko, tertinggi 41 $(62,1 \%)$ dengan pola asuh orang tua secara demokratis, sedangkan dantara remaja yang berperilaku seksual beresiko, tertinggi $25(75,8 \%)$ yang diasuh secara penelantaran.

Widyarso (dalam Amalia 2012, hlm.7) mengemukakan bahwa orang tua mempunyai peranan penting dalam menjaga perilaku generasi muda karena orang tua merupakan contoh bagi remaja. Orang tua sendiri, baik karena ketidaktahuannya ataupun karena sikapnya yang masih tabu berbicara mengenai seks dengan anaknya, ketidakterbukaan kepada anak malah cenderung membuat jarak dengan anaknya. Pola asuh orang tua mempengaruhi segala bentuk perilaku maupun pola pikir anak. Orang tua sebagai teladan bagi anak hendaknya 
lebih menjaga sikap demi generasi muda. Apabila sikap yang buruk dari orang tua tertanam dalam cara bergaul remaja, maka akan menjadi hal yang sulit untuk merubahnya dan mengoreksinya.

\section{METODE PENELITIAN}

Penelitian yang digunakan adalah jenis penelitian deskriptif analitik kuantitatif dengan pendekatan "Cross Sectional". Cross Sectional adalah suatu peneliti untuk mempelajari dinamika korelasi antara faktor-faktor resiko dengan efek, dengan cara pendekatan, observasi atau pengumpulan data sekaligus pada suatu saat (point time approach) (Notoatmodjo 2010, hlm.37-38). Sebagai variabel independen pada penelitian ini adalah pola asuh orang tua, sedangkan untuk variabel dependennya adalah perilaku berpacaran.

Lokasi penelitian dilakukan di SMAN 6 Depok. Alasan memilih tempat penelitian di SMAN 6 Depok karena karakteristik sampel memenuhi syarat yang telah diterapkan sebelumnya dan selama ini belum pernah dilakukan penelitian terhadap siswa/siswi SMAN 6 Depok mengenai pola asuh orang tua dengan perilaku mereka dalam berpacaran. Waktu penelitian disesuaikan dengan jadwal penelitian dari FIKES UPN "VETERAN" JAKARTA, serta izin dari pihak SMAN 6 Depok yaitu pada bulan Juni 2015.

\section{HASIL PENELITIAN}

Berikut akan disajikan hasil penelitian hubungan pola asuh orang tua dengan perilaku berpacaran di SMAN 6 Depok. Tabel-tabel berikut akan dikelompokkan berdasarkan analisa univariat yang terdiri dari data kategorik dan kategorik, sedangkan analisa bivariat akan dijabarkan satu persatu untuk mengetahui hubungan variabel independen dengan dependen.

\section{Analisa Univariat}

\section{a. Jenis Kelamin Responden}


Tabel 2 Distribus Frekuensi Responden Berdasarkan Jenis Kelamin Pada Remaja Kelas XI di SMAN 6 Depok

\begin{tabular}{|c|c|c|}
\hline $\begin{array}{c}\text { Jenis Kelamin } \\
\text { Responden }\end{array}$ & Frekuensi & Persentase (\%) \\
\hline laki-laki & 81 & $43,3 \%$ \\
\hline Perempuan & 106 & $56,7 \%$ \\
\hline total & 187 & $100 \%$ \\
\hline
\end{tabular}

Berdasarkan tabel 2 menunjukkan bahwa dari 187 responden yang diteliti di SMAN 6 Depok, didapatkan responden yang berjenis kelamin laki-laki sebanyak 81 responden $(43,3 \%)$, sedangkan responden yang berjenis kelamin perempuan sebanyak 106 responden $(56,7 \%)$. Kebanyakan responden berjenis kelamin perempuan karena mayoritas responden yang bersekolah di SMAN 6 berjenis kelamin perempuan.

Hasil penelitian ini didukung oleh teori Pangkahilan dalam Soetjiningsih (2004), fungsi seksual remaja perempuan lebih cepat matang, tetapi pada perkembangannya remaja laki-laki lebih aktif secara seksual dari pada perempuan. Laki-laki mengikut aturan pacaran yang proaktif, sementara perempuan bersikap reaktif. Laki-laki memulai kencan (meminta dan merencanakannya), memula interaksi sosial (melakukan kontak fisik, bermesraan dan berciuman) sedangkan perempuan berespon terhadap gerak-gerik seksual. Berdasarkan data diatas yang sudah dilakukan oleh peneliti di SMAN 6 Depok dengan 187 responden dapat disimpulkan bahwa sebagian besar responden berjenis kelamin perempuan.

\section{b. Usia Responden}

Tabel 3 Distribus Frekuensi Responden Berdasarkan Usia Pada Remaja Kelas XI di SYAN 6 Depok

\begin{tabular}{|c|c|c|}
\hline $\begin{array}{c}\text { Usia } \\
\text { Responden }\end{array}$ & Frekuensi & Persentase (\%) \\
\hline$<16$ tahun & 6 & $32 \%$ \\
\hline$\geq 16$ tahun & 181 & $96,8 \%$ \\
\hline total & 187 & $100 \%$ \\
\hline
\end{tabular}

Berdasarkan tabel 3 menunjukkan bahwa dari 187 responden yang diteliti di SMAN 6 Depok, didapatkan responden yang berusia $<16$ tahun sebanyak 6 responden (32\%), sedangkan responden yang $\geq 16$ tahun sebanyak 181 responden $(96,8 \%)$. Kebanyakan rata-rata responden berusia $\geq 16$ 
tahun dan tidak menutup kemungkinan responden berusia < 16 tahun, karena pada masa-masa sekolah menengah atas pada responden kelas XI berusia 16 tahun. Disinilah para responden merasa dirinya ingin mencari jati diri dan ingin mencoba-coba bahkan ingin melakukan hal yang semestinya karena pada masa ini adalah masa dimana responden mengalami masa-masa pubertas.

Hal ini diperkuat oleh teori Papalia dan Olds (dalam Jahja 2011, hlm.220), Usia remaja merupakan masa transisi perkembangan antara anak-anak dan dewasa yang pada umumnya dimulai pada usia 12-13 dan berakhir pada usia sekitar akhir belasan tahun atau dua puluh tahun. Pada usia ini responden masih berada pada rentang usia remaja muda sehingga rasa ingin tahu pada seksual mulai berkembang dan ada dorongan yang kuat untuk mengetahui seksualitas secara lebih jauh dan ada rasa ingin mencoba hal-hal yang baru, dengan bertambahnya umur seseorang akan terjadi perubahan pada aspek fisik dan pskologis (mental) (Mubarak, 2007). Berdasarkan data diatas yang sudah dilakukan oleh peneliti di SMAN 6 Depok dengan 187 responden dapat disimpulkan bahwa sebagian besar responden berusia $\geq 16$ tahun.

\section{c. Pola Asuh Orang Tua}

Tabel 4 Distribus Frekuensi Responden Berdasarkan Pola Asuh Orang

\begin{tabular}{|c|c|c|}
\hline \multicolumn{2}{|c|}{ Tua Pada Remaja Kelas XI di SMAN 6 Depok } \\
\hline $\begin{array}{c}\text { Pola Asuh } \\
\text { Orang Tua } \\
\text { Responden }\end{array}$ & Frekuensi & Persentase (\%) \\
\hline Kurang baik & & \\
\hline Baik & 101 & $46,0 \%$ \\
\hline Total & 187 & $54,0 \%$ \\
\hline
\end{tabular}

Berdasarkan tabel 4 menunjukkan bahwa dari 187 responden yang diteliti di SMAN 6 Depok, didapatkan responden yang memiliki pola asuh orang tua yang kurang baik sebanyak 86 responden $(46,0 \%)$, sedangkan responden yang memiliki pola asuh orang tua yang baik sebanyak 101 responden $(54,0 \%)$. Kebanyakan dari responden memiliki pola asuh yang baik karena rata-rata orang tua mereka memperhatikan setiap aktivitas mereka dalam sehari-hari bahkan 
dalam hal bergaul dengan lawan jenis dan memberikan pola asuh yang baik. Pola asuh merupakan pola interaksi antara orang tua dan anak yaitu bagaimana cara sikap atau perilaku orang tua saat berinteraksi dengan anak, mengajarkan nilai atau norma, memberikan perhatian dan kasih sayang serta menunjukkan sikap dan perilaku baik sehingga dijadikan panutan bagi anaknya (Dariyo A, 2004). Berdasarkan data diatas yang sudah dilakukan oleh peneliti di SMAN 6 Depok dengan 187 responden dapat disimpulkan bahwa sebagian besar responden memiliki pola asuh yang baik.

\section{d. Perilaku Berpacaran}

Tabel 5 Distribus Frekuensi Responden Berdasarkan Perilaku

Berpacaran Pada Remaja Kelas XI di SMAN 6 Depok

\begin{tabular}{|c|c|c|}
\hline $\begin{array}{c}\text { Perilaku } \\
\text { Berpacaran }\end{array}$ & Frekuensi & Persentase (\%) \\
\hline Tidak sehat & 74 & $39,6 \%$ \\
\hline Sehat & 113 & $60,4 \%$ \\
\hline Total & 187 & $100 \%$ \\
\hline
\end{tabular}

Berdasarkan tabel 5 menunjukkan bahwa dari 187 responden yang diteliti di SMAN 6 Depok, didapatkan responden yang memiliki perilaku berpacaran yang tidak sehat sebanyak 74 responden (39,6 \%), sedangkan responden yang memiliki perilaku berpacaran yang sehat sebanyak 113 responden $(60,4 \%)$. Kebanyakan responden berperilaku pacaran yang sehat karena mereka merasa bahwa pacaran yang tidak sehat sudah diluar batas kewajaran, dan mereka mengikuti peraturan yang diberikan oleh orang tua untuk fokus dalam belajar. Berdasarkan data diatas yang sudah dilakukan oleh peneliti di SMAN 6 Depok dengan 187 responden dapat disimpulkan bahwa sebagian besar responden berperilaku pacaran sehat.

\section{Analisa Bivariat}

\section{a. Hubungan Jenis Kelamin}

\section{Dengan Perilaku Berpacaran}

Tabel 6 Hubungan Jenis Kelamin dengan Perilaku Berpacaran Pada Remaja di SUAN 6 Depok

\begin{tabular}{|c|c|c|c|c|c|c|c|c|}
\hline \multirow{3}{*}{$\begin{array}{c}\text { Jenis } \\
\text { Kelami } \\
\text { n }\end{array}$} & \multicolumn{4}{|c|}{ Perilaku Berpacaran } & \multirow{2}{*}{\multicolumn{2}{|c|}{ Total }} & \multirow{3}{*}{$\begin{array}{c}\text { OR } \\
(95 \% \mathrm{CI})\end{array}$} & \multirow[t]{3}{*}{ P value } \\
\hline & \multicolumn{2}{|c|}{ Tidak sehat } & \multicolumn{2}{|c|}{ Sehat } & & & & \\
\hline & $\mathrm{N}$ & $\%$ & $\mathrm{~N}$ & $\%$ & $\mathrm{~N}$ & $\%$ & & \\
\hline Laki-laki & 43 & 53,1 & 38 & 46,9 & 81 & 100 & & \\
\hline $\begin{array}{c}\text { Perempu } \\
\text { an }\end{array}$ & 31 & 29,2 & 75 & 70,8 & 106 & 100 & $\begin{array}{c}2,738 \\
1,496-5,011\end{array}$ & 0,002 \\
\hline Total & 74 & 39,6 & 113 & 60,4 & 187 & 100 & & \\
\hline
\end{tabular}


Hasil analisis hubungan antara jenis kelamin dengan perilaku berpacaran pada remaja di SMAN 6 Depok, bahwa dari 187 responden yang diteliti, sebanyak 81 responden berjenis kelamin laki-laki. Jumlah tersebut sebanyak $38(46,9 \%)$ responden yang berjenis kelamin laki-laki berperilaku pacaran sehat, dan sebanyak $43(53,1 \%)$ responden berjenis kelamin laki-laki berperilaku pacaran tidak sehat. Selain itu dari 106 responden yang berjenis kelamin perempuan, 75 (70,8\%) responden yang berperilaku pacaran sehat, dan 31 $(29,2 \%)$ responden berperilaku pacaran tidak sehat.

Hasil uji statistik diperoleh nilai $\mathrm{P}$ value $=0,002(\mathrm{P}$ value $<\alpha=0,05)$, maka dapat disimpulkan ada hubungan antara jenis kelamin dengan perilaku berpacaran pada remaja. Hasil analisis diperoleh pula nilai $\mathrm{OR}=2,738$, artinya responden yang berjenis kelamin perempuan mempunyai faktor resiko 2,738 kali untuk melakukan perilaku pacaran yang sehat dibanding responden yang berjenis kelamin laki-laki. Kebanyakan jenis kelamin perempuan berperilaku pacarannya yang sehat dibanding laki-laki karena laki-laki lebih terbuka dan lebih aktif dalam seksual.

Hasil penelitian ini sejalan dengan hasil penelitian yang dilakukan oleh Damayanti (2006) pada pelajar SLTA di DKI Jakarta diperoleh bahwa ada hubungan jenis kelamin dengan perilaku beresiko pada pelajar. Hal ini diperkuat oleh teori (Santrok, 2003), secara umum dipercaya bahwa wanita lebih mengharapkan perhatian dari pasangan, sementara itu laki-laki lebih tertarik dengan masalah seksual. Pada masa remaja laki-laki menunjukkan minat seksual yang lebih kuat dari pada wanita. Seperti yang dinyatakan oleh Izzaty (dalam Aguma, 2014) bahwa fungsi seksual remaja perempuan lebih cepat matang dari pada laki-laki, tetapi pada perkembangannya remaja laki-laki lebih aktif secara seksual dari pada perempuan, hal 
ini dikarenakan adanya perbedaan sosialisasi seksual antara remaja perempuan dengan remaja lakilaki.

Hasil penelitian ini tidak sejalan dengan hasil penelitian (Harnomsari, 2011) dengan judul "hubungan kelompok teman sebaya dengan perilaku berpacaran pada remaja usia 14-17 tahun di SMK SANDIKTA Bekasi tahun 20011. Hasil statistik didapatkan nilai $\mathrm{P}$ value $=0,170$ dengan nilai $\mathrm{OR}=1,583$, sehingga dapat disimpulkan tidak terdapat hubungan yang bermakna antara jenis kelamin dengan perilaku berpacaran. Hasil penelitian ini ternyata mayoritas responden di SMAN 6 Depok yang berjenis kelamin perempuan berperilaku pacaran sehat, karena laki-laki lebih aktif dalam seksual, serta dalam hal seksul responden lakilaki lebih terbuka dibanding perempuan walaupun perempuan dalam fungsi seksualnya lebih cepat matang dan kebanyakan responden dari yang diteliti adalah perempuan.

\section{b. Hubungan Usia dengan Perilaku Berpacaran}

Tabel 7 Hubungan Usia dengan Perilaku Berpacaran Pada Remaja di

SMAN 6 Depok

\begin{tabular}{|c|c|c|c|c|c|c|c|c|}
\hline \multirow[t]{3}{*}{ Usia } & \multicolumn{4}{|c|}{ Perilaku Berpacaran } & \multirow{2}{*}{\multicolumn{2}{|c|}{ Total }} & \multirow{3}{*}{$\begin{array}{c}\text { OR } \\
(95 \% \mathrm{CI})\end{array}$} & \multirow{3}{*}{$\begin{array}{c}\mathrm{P} \\
\text { value }\end{array}$} \\
\hline & \multicolumn{2}{|c|}{ Tidak sehat } & \multicolumn{2}{|c|}{ Sehat } & & & & \\
\hline & $\mathrm{N}$ & $\%$ & $\mathrm{~N}$ & $\%$ & $\mathrm{~N}$ & $\%$ & & \\
\hline $\begin{array}{l}<16 \\
\text { Tahun }\end{array}$ & 2 & 33,3 & 4 & 66,7 & 6 & 100 & & \\
\hline $\begin{array}{l}\geq 16 \\
\text { Tahun }\end{array}$ & 72 & 39,8 & 109 & 60,2 & 181 & 100 & $0,135-4,241$ & 1,000 \\
\hline Total & 74 & 39,6 & 113 & 60,4 & 187 & 100 & & \\
\hline
\end{tabular}

Hasil analisis hubungan antara usia dengan perilaku berpacaran pada remaja di SMAN 6 Depok, bahwa dari 187 responden yang diteliti, sebanyak 6 responden yang berusia $<16$ tahun. Jumlah tersebut ada sebanyak $4(66,7 \%)$ responden yang berusia $<16$ tahun berperilaku pacaran sehat dan sebanyak $2(33,3 \%)$ responden yang berusia $<16$ tahun berperilaku pacaran tidak sehat. Sedangkan 181 responden yang berusia $\geq 16$ tahun, ada 109 (60,2 \%) yang berperilaku pacaran sehat dan 72 $(39,8 \%) \quad$ responden yang berperilaku pacaran tidak sehat. Hasil uji statistik diperoleh nilai $\mathrm{P}$ value $=1.000(\mathrm{P}$ value $>\alpha=0,05)$, maka dapat disimpulkan tidak ada 
hubungan antara usia dengan perilaku berpacaran pada remaja. Hasil analisis diperoleh pula nilai $\mathrm{OR}=0,757$, artinya usia $<16$ dan $\geq 16$ mempunyai peluang 0,757 kali untuk melakukan perilaku pacaran yang sehat.

Hal ini sejalan dengan hasil penelitian yang dilakukan oleh Harnomsari (2011) dengan judul "hubungan kelompok teman sebaya dengan perilaku berpacaran pada remaja usia 14-17 di SMK Sandikta Bekasi” menunjukkan bahwa hasil uji statistik didapatkan nilai $\mathrm{P}$ value $=0,784$ berarti $\mathrm{P}$ value $>0,05$. kesimpulannya tidak terdapat hubungan antara usia dengan perilaku berpacaran pada remaja di SMK Sandikta Bekasi.

Penelitian ini tidak sejalan dengan hasil penelitian yang dilakukan oleh Amalia (2012) bahwa salah satu faktor yang mempengaruhi gaya pacaran remaja adalah usia. Hasil ini menunjukkan bahwa hampir seluruh remaja berusia 1618 tahun. Pada usia 16-18 tahun remaja memasuki tahap pertengahan yang ditandai dengan berkembangnya kemampuan berfikir yang baru, teman sebaya masih memiliki peranan yang penting. Namun, individu sudah mampu mengarahkan diri sendiri. Selain itu penerimaan dari lawan jenis menjadi penting bagi individu sehingga menggiring remaja ke gaya pacaran yang negatif dengan ciri adanya tidakan kekerasan baik secara fisik, psikis, social maupun seksual.

Hasil penelitian ini ternyata mayoritas responden di SMAN 6 Depok yang berusia $\geq 16$ tahun lebih banyak berperilaku pacaran yang sehat, namun tidak menutup kemungkinan bahwa responden yang berusia $<16$ tahun berperilaku pacaran yang sehat, karena pada umumnya remaja yang duduk di kelas XI sekolah menengah atas mayoritas berusia antara 15 tahun sampai 18 tahun, rata rata dari mereka kebanyakan berperilaku pacaran yang sehat.

\section{c. Hubungan Pola Asuh Orang Tua dengan Perilaku Berpacaran}


Tabel 8 Hubungan Pola Asuh Orang Tua dengan Perilaku

Berpacaran Pada Remaja di SUAN 6 Depok

\begin{tabular}{|c|c|c|c|c|c|c|c|c|}
\hline \multirow{2}{*}{$\begin{array}{l}\text { Pola } \\
\text { Asuh } \\
\text { Orang }\end{array}$} & \multicolumn{4}{|c|}{ Perilaku Berpacaran } & \multirow{2}{*}{\multicolumn{2}{|c|}{ Total }} & \multirow{3}{*}{$\begin{array}{c}\text { OR } \\
(95 \% \mathrm{CI})\end{array}$} & \multirow{3}{*}{\begin{tabular}{|c|}
$\mathrm{P}$ \\
value
\end{tabular}} \\
\hline & \multicolumn{2}{|c|}{ Tidak sehat } & \multicolumn{2}{|c|}{ Sehat } & & & & \\
\hline $\begin{array}{c}\text { Orang } \\
\text { Tua }\end{array}$ & $\mathrm{N}$ & $\%$ & $\mathrm{~N}$ & $\%$ & $\mathrm{~N}$ & $\%$ & & \\
\hline $\begin{array}{l}\text { Kurang } \\
\text { Baik }\end{array}$ & 44 & 51,2 & 42 & 48,8 & 86 & 100 & $\begin{array}{c}2,479 \\
1,360-4,521\end{array}$ & 0,004 \\
\hline Baik & 30 & 29,7 & 71 & 70,3 & 101 & 100 & & \\
\hline Total & 74 & 39,6 & 113 & 60,4 & 187 & 100 & & \\
\hline
\end{tabular}

Hasil analisis hubungan pola asuh orang tua dengan perilaku berpacaran pada remaja di SMAN 6 Depok, bahwa dari 187 responden yang diteliti, sebanyak 86 responden yang memiliki pola asuh orang tua yang kurang baik. Jumlah tersebut $42 \quad(48,8 \%)$ responden yang memiliki pola asuh orang tua kurang baik berperilaku pacaran sehat dan sebanyak $44(51,2 \%)$ responden yang memiliki pola asuh kurang baik berperilaku pacaran tidak sehat. Sedangkan dari 101 responden yang memliki pola asuh yang baik, $71 \quad(70,3 \%)$ yang berperilaku pacaran sehat dan 30 $(29,7)$ responden yang berperilaku pacaran tidak sehat. Hasil uji statistik diperoleh nilai $\mathrm{P}$ value $=$ 0,004 (P value $<\alpha=0,05)$, maka dapat disimpulkan ada hubungan antara pola asuh orang tua dengan perilaku berpacaran pada remaja. Hasil analisis diperoleh pula nilai $\mathrm{OR}=2,479$, artinya responden yang memiliki pola asuh orang tua yang baik mempunyai faktor resiko 2,479 kali untuk melakukan perilaku pacaran yang sehat dibanding responden yang memiliki pola asuh orang tua yang kurang baik.

Peneliti juga menilai pola asuh dari jenis pertanyaan negatif atau positif dan dilihat hasil nilai ratarata penjumlahan jawaban responden, jika < dari rata-rata maka pola asuhnya kurang baik dan $\geq$ rata-rata pola asuh yang baik. Hasil penelitian ini sejalan dengan penelitian yang dilakukan oleh Amalia (2012) dengan judul "gaya pacaran ditinjau dari pola asuh orang tua pada remaja kelas XI di SMA Marga 1 Lamongan" menunjukkan bahwa pola asuh tipe 6 cenderung memiliki gaya pacaran yang negatif. Sebaliknya remaja yang memiliki pola asuh tipe 3 cenderung memiliki gaya 
pacaran positif. Hasil uji korelasi Koefisien Phi hubungan pola asuh orang tua dengan gaya pacaran pada remaja (kelas XI) menggunakan spss menunjukkan $\mathrm{H}_{1}$ diterima artinya ada hubungan pola asuh orang tua dengan gaya pacaran pada remaja (kelas XI) di SMA Panca Marga 1 Lamongan. Hal tersebut diperkuat oleh teori Widyarso (2006), bahwa pola asuh orang tua sangat berperan penting dalam menjaga perilaku generasi muda karena orang tua merupakan contoh bagi remaja sifat dan perilaku anak sangat dipengaruhi dengan pola asuh kedua orang tua mereka, terlalu memanjakan atau memandang sebelah mata keberadaan mereka bisa berakibat buruk terhadap kepribadian mereka kelak (Surya, 2008). Berdasarkan peneliti pendahulu yang dilakukan oleh Jannah (2012) bahwa orang tua yang menerapkan bentuk pola asuh otoriter dimana, bentuk pola asuh orang tua otoriter dapat menyebabkan kesulitan bagi anak untuk bersosialisasi, sedangkan orang tua yang menerapkan bentuk pola asuh demokrasi, menampilkan perilaku moral yang baik sesuai dengan harapan, dan bentuk pola asuh orang tua permisif kurang tepat digunakan dalam menanamkan perilaku moral pada anak, karena minim dengan penanaman nilai etik moral karena orang tua hanya beranggapan semua perilaku anak yang tidak baik. Hurlock (2008) juga mengemukakan bahwa anak yang mendapatkan pola asuh yang demokratis maka anak akan tumbuh menjadi pribadi yang mampu mengendalikan diri dan secara umum memiliki perilaku diri yang baik. Sedangkan orang tua yang memberlakukan pola asuh yang otoriter anak akan cenderung memiliki perilaku yang buruk. Selain itu Hurlock juga menambahkan jika orang tua memberlakukan pola asuh yang permisif maka anak akan cenderung memiliki perilaku buruk lebih banyak bila dibandingkan perilaku baiknya, mereka cenderung pemalu, menutup diri namun jika mendapatkan teman yang mempunyai perilaku tidak 
baik maka dia dengan mudah mengikutinya.

Hasil penelitian ini ternyata mayoritas responden di SMAN 6 Depok yang memiliki pola asuh orang yang baik berperilaku pacaran yang sehat, sedangkan dari responden yang memiliki pola asuh yang kurang baik berperilaku pacaran yang tidak sehat. Hal ini disebabkan karena pola asuh asuh orang tua sangat mempengaruhi sifat dan perilaku anak-anaknya. Jika orang tua mereka menerapkan pola asuh yang baik maka anakanak mereka akan meniru kebiasaan baik yang mereka terima, dan jika orang tua mereka menerapkan pola asuh yang kurang baik anak-anaknya akan berperilaku yang kurang baik, anak akan menjadi lebih melawan kepada orang tua bahkan kepada orang lain. Anak akan menganggap apa yang mereka lakukan sesuai apa yang sudah diajarkan oleh orang tuanya dan mereka merasa orang tuanya pun tidak peduli dengan apa yang mereka lakukan.

\section{KESIMPULAN}

Berdasarkan hasil penelitian yang dilakukan terhadap 187 responden tentang Hubungan pola asuh orang tua dengan perilaku berpacaran pada remaja di SMAN 6 Depok, maka dapat disimpulkan sebagai berikut:

a. Karakteristik responden menurut (usia dan jenis kelamin), menunjukkan bahwa dari jumlah 187 siswa/ siswi di SMAN 6 Depok kelas XI dapat dilihat dari segi usia sebagian besar mayoritas berusia $\geq 16$ tahun dengan jumlah $181(96,8 \%)$ dan jumlah dari segi jenis kelamin mayoritas berjenis kelamin perempuan yaitu sebanyak 106 responden $(56,7 \%)$.

b. Gambaran pola asuh orang tua di SMAN 6 Depok, menunjukkan bahwa dari 187 responden sebagian besar memiliki pola asuh yang baik yaitu sebanyak 101 responden $(54 \%)$.

c. Gambaran perilaku berpacaran pada remaja di SMAN 6 Depok, menunjukkan bahwa dari 187 responden sebagian besar memiliki perilaku berpacaran 
yang sehat yaitu sebanyak 113

responden $(60,4 \%)$.

d. Hasil uji statistik (chi square) antara hubungan jenis kelamin dengan perilaku pacaran diperoleh nilai $\mathrm{P}$ value $=0,002(\mathrm{P}$ value $<\alpha=0,05)$, maka dapat disimpulkan ada hubungan antara jenis kelamin dengan perilaku berpacaran remaja di SMAN 6 Depok. OR $=2,738$, artinya responden yang berjenis kelamin perempuan mempunyai faktor resiko 2,738 kali untuk melakukan perilaku pacaran yang sehat dibanding responden yang berjenis kelamin laki-laki

e. Hasil uji statistik (chi square) antara usia dengan perilaku berpacaran diperoleh nilai $\mathrm{P}$ value $=1.000(\mathrm{P}$ value $>\alpha=$ 0,05), maka dapat disimpulkan tidak ada hubungan antara usia dengan perilaku berpacaran pada remaja di SMAN 6 Depok. OR= 0,757 , artinya usia $<16$ dan $\geq 16$ mempunyai peluang 0,757 kali untuk melakukan perilaku pacaran yang sehat.

f. Hasil uji statistic (chi square) antara pola asuh orang tua dengan perilaku berpacaran diperoleh nilai $\mathrm{P}$ value $=0,004(\mathrm{P}$ value $<\alpha=0,05)$, maka dapat disimpulkan ada hubungan antara pola asuh orang tua dengan perilaku berpacaran pada remaja di SMAN 6 Depok. OR=2,479, artinya responden yang memiliki pola asuh orang tua yang baik mempunyai faktor resiko 2,479 kali untuk melakukan perilaku pacaran yang sehat dibanding responden yang memiliki pola asuh orang tua yang kurang baik.

\section{SARAN}

Berdasarkan hasil penelitian dan pembahasan yang telah diuraikan maka ada beberapa saran yang dijadikan pertimbangkan yaitu:

a. Bagi remaja

Remaja agar lebih bisa membedakan perilaku mana yang baik dan mana yang tidak, serta remaja harus berhati-hati dalam bergaul dan menjaga kehormatan diri mereka karena pada perkembangan saat ini remaja menganggap remeh akan hal yang seharusnya tabu dilakukan. 
b. Bagi orang tua

Orang tua agar lebih memperhatikan anaknya dalam bergaul serta lebih banyak berkomunikasi kepada anak agar anak remaja bisa mengungkapkan perasaan mereka, karena peran orang tua sangatlah penting bagi perilaku anaknya terutama orang tua yang memiliki anak remaja dan orang.

c. Bagi perawat

Pihak kesehatan khususnya pada perawat mengenai judul hubungan pola asuh orang tua dengan perilaku berpacaran pada remaja agar bisa lebih sering mengadakan penyuluhan-penyuluhan mengenai kesehatan reproduksi, peran orang tua maupun mengenai bagaimana bergaul yang baik dengan lawan jenis agar tidak timbul terjadinya hamil di luar nikah.

d. Bagi institusi pendidikan

Institusi pendidikan untuk menerapkan materi-materi tentang hubungan pola asuh orang tua dengan perlaku berpacaran kepada mahasiswa/mahasiswi, agar mahasiswa/mahasiswi lebih mengenal pengetahuannya tentang pola asuh orang tua mana yang baik dan kurang baik serta lebih memperluas pengetahuannya tentang perilaku pacaran mana yang sehat dan mana yang tidak sehat.

e. Bagi perkembangan ilmu pengetahuan

Mahasiswa agar lebih mengembangkan ilmu keperawatannya khususnya dalam masalah pola asuh orang tua dalam mengasuh anak-anaknya serta perilaku pacaran pada remaja yang sehat dan tidak sehat dengan mengikuti seminar dan pelatihan.

f. Bagi peneliti selanjutnya Mengharapkan peneliti selanjutnya dapat menambahkan variabel yang lebih banyak lagi yang dapat mempengaruhi perilaku berpacaran pacara pada remaja seperti faktor pengetahuan, pendidikan orang tua, pekerjaan orang tua, pengaruh teman sebaya, paparan media massa karena perilaku pacaran tidak hanya dipengaruhi oleh pola asuh saja. Serta peneliti bisa lebih mencermati dalam pembuatan pertanyaan-pertanyaan, memperluas daerah penelitian dan 
memilih subjek yang memenuhi kriteria yang ditentukan. Peneliti selanjutnya juga diharapkan bisa lebih dekat lagi dalam melakukan pendekatan dan kepercayaan kepada responden agar memperoleh data yang sesuai dengan dengan apa yang diinginkan oleh peneliti.

\section{REFERENSI}

Aini, AN 2012, Studi Diskriptif Tentang Gaya Pacaran Siswa SMA Kota Semarang, Dinamika Kebidanan, vol.2, no.1, Januari 2012.

Aguma, 2014, Hubungan Pola Asuh Orang Tua Dengan Perilaku Seksual Remaja Di SMA Tri Bhakti Pekan Baru, Jurnal, Program Ilmu Keperawatan Universitas Riau.

Amalia, A 2012, Gaya Pacaran Ditinjau Dari Pola Asuh Orang Tua Pada Remaja Kelas XI Di SMA Panca Marga 1 Lamongan, Surya, vol.03, no.XIII, Desember 2012.

Apra, E 2014, Hubungan pola asuh orang tua dengan tingkat kecemasan anak pada adaptasi sekolah, Skripsi, Universitas Pembangunan "VETERAN" Jakarta.
Arikunto, S 2010, Prosedur Penelitan Suatu Pendekatan Praktik, Jakarta: Bineka Cipta.

Arramdani, 2010, Perilaku Pacaran Remaja (Studi Kasus di SMA Nusa Bhakti) Semarang, Jurnal, Universitas Dian Nuswantoro Semarang.

Astuti, 2009, Hubungan Kelompok Teman Sebaya (Peer Group) Dengan Perilaku Berpacaran Pada Remaja Di SMA NEGERI 90 Jakarta Selatan, Laporan Penelitian, Universitas Indonesia.

Banun, F 2013, Faktor-Faktor Yang Berhubungan Dengan Perilaku Seksual Pranikah Pada Mahasiswa Semester V STIkes X Jakarta Timur 2012, Jurnal, Ilmiah Kesehatan, Vol.5, no.1, januari 2013.

Dariyo, A 2004, Psikologi Perkembangan Remaja, Bogor: Ghalia Indonesia.

Dharma, KK 2011 Metodologi Penelitian Keperawatan; Panduan Melaksanakan dan Menerapkan Hasil Penelitian, Jakarta : TIM.

Dimyanti, V 2013, BKKBN Perilaku Pacaran Remaja Mengkhawatirkan. di akses tanggal 25-2-2015 jam 12.35 http://www.jurnas.com/news/11 3449/BKKBN_Perilaku_Pacara n_Remaja_Mengkhawatirkan_2 $\underline{013 / 1 / \text { Sosial_Budaya/Kesehata }}$ n. 
Evi, 2013, Perilaku Seksual Remaja Yang Berpacaran di SMA Negeri 2 Kairatu Kabupaten Seram Bagian Barat', Jurnal, Unhas Makasar.

Fakih, M 2006, Analisis Gender dan Transformasi Sosial, Yogyakarta: Pustaka Pelajar.

Indriani, D dan Asmuji 2014, Buku Ajar Keperawatan Maternitas, Jakarta: AR-RUZZ Media.

Jahja, Y 2011, Psikologi Perkembangan, Jakarta :Kencana.

Heryana, R 2011, Banyak Gadis Tidak Perawan, Radar Cikarang.

Hastono, SP 2007, Analisa Data Kesehatan, Jakarta: Rajawali Pers.

Kriswahyuni, 2013, Hubungan Pengetahuan Tentang Pacaran Dengan Perilaku Seks Pranikah Pada Remaja Kelas XI Di UPTD SMA NEGERI 1 Gurah Kabupaten Kediri, Jurnal, STIKes Bhakti Mulia Kediri.

Kumalasari dan Andyantoro, 2012, Kesehatan Reproduksi; Untuk Mahasiswa Kebidanan Dan Keperawatan, Jakarta: Salemba Medika.

Mardiya, 2013, Hari Kependudukan Sedunia Tahun 2013 Saatnya Tahu Dan Peduli Terhadap Masalah Remaja, Artikel.
Muliyati, 2012, Faktor-Faktor Yang Berhubungan Dengan Perilaku Gaya Pacaran Pada siswa SMU X dan MAN Y Kabupaten Sidrap Provinsi Sulawesi Selatan, Skripsi. Universitas Indonesia.

Murtiyani, N 2011, Hubungan Pola Asuh Orang Tua Dengan Kenakalan Remaja Di Rw $V$ Kelurahan Sidokare Kecamatan Sidoarjo, Jurnal Keperawatan, vol.01, no.01, Desember 2011.

Notoatmodjo, 2003, Pendidikan Dan Perilaku Kesehatan, Jakarta: PT Rineka Cipta.

Notoatmodjo, 2010, Promosi Kesehatan; Teori \& Aplikasi, Jakarta: PT Rineka Cipta.

Notoatmodjo, 2011, Kesehatan Masyarakat; Ilmu \& Seni, Jakarta :PT Rineka Cipta.

Nurhayanti, 2012, Tipe Pola Asuh Orang Tua Yang Berhubungan Dengan Perilaku Bullying di SMA Kabupaten Semarang, Jurnal, Sekolah Tinggi Ilmu Kesehatan Ngudi Waluyo Ungaran.

Potter dan Perry, 2009, Fundamental Keperawatan, Edisi 7, Jakarta: Salemba Medika.

Pratiwi, NE 2009, Gambaran Konsep Pacaran dan Perilaku Pada Remaja Awa', Skripsi, Universitas Indonesia.

Pujiati, 2013, Gambaran Perilaku Pacaran Remaja di Pondok 
Pesantren Putri K.H Sahlan Rosjdi (UNIMUS) Semarang, Jurnal, Universitas Muhammadiah Semarang.

Putra, SR 2012, Panduan Riset Keperawatan dan Penulisan Ilmiah, Jakarta: D-MEDIKA.

Sejati, F 2008, Hubungan Antara Pengaruh Faktor Lingkungan Terhadap Perilaku Pacaran Pada Remaja di SMA Patriot Bekasi tahun 2008, Skripsi, FKMUI.

Setiadi, 2013, Konsep dan Praktik Penulisan Riset Keperawatan, Jakarta: Graha Ilmu.

Sudarma, M 2008 Sosiologi Untuk Kesehatan, Jakarta: Salemba Medika.

Surbakti, 2009, Kenalilah Anak Remaja Anda, Jakarta: PT Elex Meda Komputindo.

Soetjiningsih, 2010, Tumbuh Kembang Remaja Dan
Permasalahannya, Jakarta: CV, Sagung Seto.

Tim Penulis Poltekes Depkes Jakarta 1, 2012, Kesehatan Remaja: Problem dan Solusinya, Jakarta : Salemba Medika.

Umsoniah, 2005, Perilaku Berpacaran Santriwati (Studi Deskriptif Santriwati Pondok Pesantren Kedunglo Al Munadhdhoroh Desa Bandar Lor Kecamatan Mojoroto Kota Madya Kediri), Jurnal, Universitas Jember.

Wildsmith, E 2013, 'Dating and Sexual Relationship',Trends Child.

Wong, 2008, Buku Ajar Keperawatan Pediatrik, Jakarta: EGC.

Yusuf, $\quad$ S 2009, Psikologi Perkembangan Anak Dan Remaja, Bandung: PT Remaja Rosdakarya. 